\title{
THE FEASIBILITY OF USING PERSIAN GARDEN ELEMENTS IN TODAY'S URBAN AREAS TOWARD SOCIAL INTERACTION ENHANCEMENT
}

\author{
Mohammad Rasoul Khoshouie \\ M.A. in Architecture, Qazvin Branch, Islamic Azad University, Qazvin, Iran \\ mkhoshoui@gmail.com \\ Fariba Alborzi
}

Ph.D., Member of academic board, Department of Architecture, Qazvin Branch, Islamic Azad

University, Qazvin, Iran

faalborzi@yahoo.com

\begin{abstract}
Nowadays in cities, the pale role and weak existence of human presence in urban spaces and its consequences as social evolutions is the most clear and definite mater than anytime. Cities in the history through their human scale, were place places for the people, given the widespread presence and growing tendency to the use of cars and the machinated life, gradually, the man replaced its place with car which, incidentally, is the product of himself. As a result of such conditions, have been gradually faded the interaction and reactions between citizens and the city, the outcome of such an event is common dejection and depression in today's human societies. The need to return of people to the city and their role as active citizens are of the reasons of the existence of urban spaces. Squares, walkways and urban green spaces can be seen as the spaces that are able to meet the basic needs of people. Persian Garden is a phenomenon that over thousands of years, have played its role as a place for people. A lively and vibrant place where human through being in it, will step into a world different from their common environment. This article aims to evaluate the possibility of using the principles, elements and various systems of Persian Garden in urban green spaces so that in this way to be increased the desire of people for presence in these areas and positively affect social interaction and activities of people. Therefore, in the early sections, will be provided a brief introduction to the Persian Garden and then will be examined the various elements. In addition, at the end of the article, will be examined the terms of the use of the elements of Persian gardens in urban spaces.
\end{abstract}

Keywords: Persian Garden, urban space, social interactions

\section{INTRODUCTION}

The today's world is experiencing a severe crises of nerve, a crisis which is a result of the modern human life. "According to the World Health Organization, seventy percent of human physical illness is caused by stress and nervous crises "(Shahcheraghi, 2010, 33). The neurological disorders and subsequent pressures on human cause some confusion and distress among different people. Increasing congestion and rapid population growth in today's cities and settlements on the one hand, increase the nervous crises and on the other hand, the growth and development of technology can be take into account as the basis for many of the problems of today's world. The fact is that the technology is more advanced most humans are away from each other. Nowadays machine's life caused that instead of interacting face to face, people interact to each other through developed mechanisms which this represents a reduction of social interactions in today's world. According to psychologists and researchers in environmental psychology, injuries caused by overcrowding in human life are found in forms of disease, aggression, suicide, crime and other social problems.

In fact, this crisis caused by population growth if the current trend of future urban planning and architecture continues, not only will not be less in future but also will be increased dramatically. Another factor of the present moral crisis is due to being away from nature. The 
primitive man who once had a peaceful relationship with nature, over time and with the settling of man, reached the control and exploitation of it. If factors such as the poor urban planning, dramatic population growth, the separation of nature and the technology development are taken into account as the main causes of today's moral crisis in the world, it is necessary to rely on different solutions such as considering nature in urbanism, the appropriate use of advanced technology tools and relying on the ethical and religious approaches. The role of Persian Garden is to create a place through which the environment and the human become one entity, "people are their place and a place is the place's people" (Ralph, 2010, 39). Persian Garden have long been burdened mission that the mission is to create a pleasurable atmosphere. During the history, Persian Garden has aimed to create a quiet place through stimulation of the five senses. A place for being namely the human experiences presence in a space in the divine world at a place in this world.

\section{PERSIAN GARDEN}

Identification of garden is a long way, garden and the experience of the garden layout dates back to thousands of years ago. The garden is a place for human use where conveys a combination of the architectural elements, trees, ornamental flowers and focus on water and has been formed associated with people's taste, culture and climate of each country." Many linguists knows "Bagh (ب)" as the root word of the word garden which means the benefit and section. "(Shahcheraghi, 2010, 94). In Encyclopedia of Islam, Garden is explained as:

"A completely enclosed area where is often human-made by using flowers and plants, trees, water and special buildings which are based on the rules of geometry and beliefs." (Encyclopedia of Islam, 2002, 206). Persian Garden is a set of architectural elements. These elements in the history of this country and according to the requirements of time and specific geographic climate of any location in Iran, affected the advent of Persian garden. Elements such as wall, water, plants etc., can be called as the essential elements forming the Persian Garden which are expressed in the physical appearance. Different definitions of the Persian garden are provided that each of which speaks about the specific circumstances of this phenomenon and its effectiveness. "Persian Garden is defined as a space for relaxation and comfort and a place for profound thinking" (Mir Fendereski, 2004, 10).

\section{CAUSES OF THE ADVENT OF PERSIAN GARDEN}

During previous periods, the purpose of creating Persian Garden was to build a vibrant place. As mentioned, Iran's hot and dry climate caused that to escape the severe sunlight and overwhelming heat and sandy winds, people looked for a solution and was seeking for creating a place for relaxation. "Basically, the shading system had a decisive role and positive meaning at the climate and the birthplace of Persian Garden and can be considered as one of the important components in the garden especially in a condition that the humidity is increased by using water, the set of these two factors, forms the most basic idea of Persian Garden which is called the vibrant space "(Masoudi, 2003, 183). Various reasons are known for the rise of Persian Garden. Iran has a dry and hot climate and given that about 70 percent of Iran's land consists of hot deserts and uninhabitable lands, is necessary the need of people in this country to have a place where they are separated from their climatic conditions and puts them in another world. "The establishment of gardens in the desert, hillside and along the watercourses, in addition to creating a useful and beautiful environment, also reveals the hidden environmental potential of the region and lead to order up an ecosystem, as well" ( Behbehani, 2003, 82). Heshmatollah Motedaien looks at ritual or religious means as the main reason for the development of Persian Garden. "Researchers with different approaches, mentioned inclusion and security as the reason of the walls surrounding the Persian Garden and sometimes as a barrier to protect against the sandstorm but here, meaning-oriented researchers looked at enclosing of Persian Garden due to the religious factor in order to protect users against acts of evil. As a result, they know gardens as the true embodiment of the Avestan Eden. "(Motedaien, 1998, 411).

\section{KINDS OF PERSIA GARDENS}

Persian Gardens have been formed influenced by climate, culture, political, security conditions and other important characteristics. These various factors have affected the appearance of Persian Gardens. On the other hand, the vast extent of Iran and the cultural geography of Iran caused that over 
time and in different regions, this geographical area to Persian Garden to be appeared in different ways. Therefore, different thinkers have mentioned different categories of Persian Gardens that some of them is presented in table 1 .

Table1: kinds of Persian garden

\begin{tabular}{|l|l|}
\hline $\begin{array}{l}\text { Researcher } \\
\text { name }\end{array}$ & Kinds of Persian Garden \\
\hline $\begin{array}{l}\text { Azadeh } \\
\text { Shahcheraghi }\end{array}$ & $\begin{array}{l}\text { Kūshk Garden, Palace Garden, Home Garden, Tents Garden, Tajir Garden, Castle } \\
\text { Garden, Bed Garden, Water Gardens, Tomb Garden }\end{array}$ \\
\hline $\begin{array}{l}\text { Hossain } \\
\text { Soltanzadeh }\end{array}$ & $\begin{array}{l}\text { Orchard, Settlement Garden, Government Garden, Settlement - Government Garden, } \\
\text { Tomb Garden, The Garden Located in a Paved Land, the Garden Located in The } \\
\text { Hills, Water Garden, House Garden, Garden Located Next to the River }\end{array}$ \\
\hline $\begin{array}{l}\text { Javad } \\
\text { Mahdizadeh }\end{array}$ & State Garden, Private Garden, Public Garden \\
\hline $\begin{array}{l}\text { Gh. } \\
\text { Naeima }\end{array}$ & Orchard, Settlement Garden, Settlement - Governmental Garden, Tomb Garden \\
\hline
\end{tabular}

Reference: Author

\section{THE ELEMENTS FORMING PERSIAN GARDENS}

In history, various physical elements and systems led to creation of Persian Garden. Various categories are considered for these systems. For example, Dr. A. Shahcheraghi notes three systems of planting, water and buildings. Of course, others have their own categories. Forming the Persian Garden, is provided the geometric context related to other factors such as plants and the architecture system. Dr. Solatnzade is who presented another category in this terms.

Persian garden elements and phenomena are divided into four categories by Soltanzadeh: 1) structural elements and phenomena 2) water-based elements 3) plant-based elements 4) communication elements. Yaghob Danshdust also notes four components as essential elements of Persian garden: 1) water 2) land 3) plants 4) architecture (Speech of Mr. Danshdust in 1984 at the National University's School of Architecture). Flowingly, will be examined the elements of Persian Garden. Due to climatic and geographical conditions of the Persian Garden, the kind of cultivation can help creating a favorable conditions. Different ways to plant trees in the Persian Garden have been seen throughout the history. The types of plants used in the garden were primarily dependent on the function of geographical - climatic and regional location of the garden.

Water: water has been a basic and vital element of human life throughout the history. The consecrated aspect of water can be seen in the entire civilizations of the world. Water symbolizes purity, proliferation, moving and holiness. Has long since water can be found as a symbol in all great and old civilizations. In ancient Persia, the water has had a significant role as well. Due to the presence in a hot and dry desert in the world which the lack of water is salient there, they presented various solutions to address this shortage and lack of water that this has caused the water goes to different parts of this geographical region. Water generates garden, the main sources of water supply in Iran are rainfall and ground waters.

One of the important features of the water system in the Persian Garden is its high tendency to be seen, "when the water was usually very low and very dear, the garden architect played strange games with it and through an indescribable game, he frequently sent the water inside the ground and then brought it back " (Pirnia, 2006, 7). In the entire garden floor, water is of an important role and in addition to the functional and the aesthetic interest, they also have a philosophical interest due to that 
philosophically, water refers to concepts such as purity, freshness and life. The role of water in the Persian Garden construction is not only a functional role. The presence of water in the Persian Garden is a combination of "objective" and "sensitive" features. "The most important thing to yard up the garden was bringing water from far lands which this problem has been solved by the transfer of water through aqueducts."(Pirnia, 2013, 288).

Construction buildings: there is no sufficient information about the pre-Islamic Persian Garden. Those are available more show kennels and pools. This is the same method has continued after this period during the Islamic era.

Persian Garden, except those that have been created for the space and landscaping tombs and those were public, has been always enclosed and belonged to the kings and the rich and the garden has a private feature. For this reason and to a considerable extent, it could be somehow dependent on the design and taste of the garden's owner. So that "the location of buildings in the garden is in compliance with the complete square or rectangular internal shape of the garden space "(Shahcheraghi, 2010, 83).

So that the garden's internal landscaping system figures out a perfect geometric shape. That's why the spaces located inside the walls spread in an irregular way outward the garden. In fact, "the regular geometric formation of the inner space from the center, mainly starts from the open space and grows outward and in a closed space namely a non- visible inside-out space, suits with the irregular form of the surrounding fabric through various measures and fits to this " ( Mir Findereski , 1995, 123). Various building features in Persian Garden include: entrance building, Kūshk, service sections.

Geometry: as the simplest definition of the geometry of the Persian Garden, this can be noted "Persian Garden is a square or completely rectangular shaped area and in proportion to the volume of water that exists, this is shaped in the intended land and is segmented and divided according to the characteristics of the land and based on a regular geometry" (Shahcheraghi, 2010, 43). Persian Garden's Geometry has strong basic characteristics. Rectangular being and order are of major and general characteristics of the form of Persian Garden. This geometry and geometric coordination are due to a variety of reasons.

"Persian Garden's plan relies on attention and special application of square in the overall composition and its components "(Naeima, 2013, 21). Easily legibility of Persian Garden, preparation for agriculture and irrigation in Persian Gardens, creation of an assumed geometry in addition to the physical geometry which creates a link between the garden and the mindset of people etc., are of the results of Persian Garden's geometry.

Persian Garden's geometry emphasizes on garden's hierarchy and organizes the movement system in the garden. "The geometry of space and spatial system form the spaces based on the relationship between architectural elements including entrance, balcony, palace, the walls around etc., as well as considering the relationship between each individual element and their collection with the outer spaces so that the continuity of the main axis of each building and the garden's axes and proportions and relations between indoors and semi-open spaces such as balcony and open spaces in the garden"(Soltanzadeh, 2003, 34). Persian Garden always has a specific and regular geometry. Persian Garden's salient and obvious geometry is square and rectangular geometry. Two perpendicular axes which create a four-fold plan are the most common kind of gardens building in Iran. Sometimes these four areas are divided into smaller parts as well. Generally, these sections were accounted for diverse crofts with a variety of flowers and plants. Flowers and aromatic plants were also aromatic in order to stimulate the human sense of smell and with the birds, they cause many sounds so that they can affect human hearing. On the other hand, one of the basic and fundamental characteristics of Persian garden decoration is its axis-based plans. There are generally two axes that one is more highlighted. This axis which connects the garden entrance to the palace, is very strong. The breadth of vision and spatial extent that this axis creates is very significant. On both sides of this axis, there is a variety of flowers and plants in crofts and sometimes this axis is emphasized by planting trees on this path. The peak 
emphasize is done through a water channel. A channel full of water that passes through this axis and sometimes goes into the building, as well.

The water passing through the above route and due to its special paving, creates a specific sound. A sound that is very useful in creating a vibrant place. Iran's beliefs in the history for rulers and the position of holiness that the rulers were believed, affected the pivotal attitude of this setting. Rulers had a sacred status in the eyes of people and on the other hand, Persian Garden is the paradise's manifestation in this world. To demonstrate this attitude, the Iranian architect designed and built Persian Garden with a simple geometry. Therefore, the most important reasons of such a strong corridor in Persian Garden can be referred these beliefs and thoughts of Iranian nationals throughout history, before the arrival of Islam and after the arrival of Islam in Iran.

Introverts and extroverts have long been a problem in the evaluation of buildings and Iranian architecture. This is important to examine the Persian Garden as well. "Persian Garden architecture, unlike other lands, has been introverted like Persian buildings, "(Pirnia, 2013, 430). The introverted garden is placed in the center in form of an indoor space. In this case, the yard in addition to creating unity between the elements, creates a kind of surveying connection between them as well. Geometry in Persian Garden aims to create a harmonious and parallel relationship between the various elements of Persian Garden. A geometry in which walls, a variety of man-made buildings, courtyards and so on play role to form it.

Wall: wall is one of the most obvious and the most basic parts of the Persian garden. "All the elements shaping the Persian Garden are enclosed by walls and as a framework, wall has surrounded all these elements. Trees planted on the edge of the wall and consistent with its geometry, all are in line with the geometry of the garden's wall and add to its role as a framework "(Masoudi, 2003, 14). A variety of walls is used in Persian Garden. From the thick and strong walls resulting in the castle garden to the mesh walls that showed the Tajir Garden to the public. In general, there have been assumed various reasons and functions for wall.

Security approach can be considered as one of the functions of the garden. "Garden was not an open place and was a land surrounded by walls and no one was able to see in it from the outside"(Pirnia, $2013,430)$. So that, depending on the level of security in each period and geographic region, were changed the shapes of the walls. Maybe that's why in the Safavid era in Isfahan, gardens had netted walls which reflected the security and comfort of the region in that particular period (Safavid). Garden remains safe by walls against damages and hot and dry winds. Therefore, the climate function of the wall is of importance functions. Persian Garden is often indicative of two different worlds. One world is the garden itself and the outside world can be seen as the antithesis of the world. In this case, the wall must be known as a border and buffer the two worlds. A border not in the sense of the boundary separating these two worlds from each other but as the beginning of another world. In other words, "wall in Persian Garden separates two different worlds. While in many gardens attributed to Persian Garden, you cannot see this situation for the wall. These gardens, however, may be eligible for all the elements of Persian Garden but the salient difference between them is due to the signature feature of the environment against the essaying feature of Persian Garden in relation with the environment" ( Masoudi, 2003, 100). The reason of such a capability and ability can be sought in Iranian religious thoughts. That's why is embodied the assumption of the heaven in the body of lush gardens that is given to them as a reward for good deeds. The elements forming Persian Gardens presented in table 2.

Table 2: The elements forming Persian Gardens

\begin{tabular}{|l|l|l|l|l|l|l|l|l|l|}
\hline people & Trees & Segments & $\begin{array}{l}\text { Water } \\
\text { and } \\
\text { raceway } \\
\mathrm{s}\end{array}$ & Tents & $\begin{array}{l}\text { Canopie } \\
\mathrm{s}\end{array}$ & Pergola & $\begin{array}{l}\text { Pool and } \\
\text { fountain }\end{array}$ & $\begin{array}{l}\text { Fences } \\
\text { and } \\
\text { hedgero } \\
\text { Ws }\end{array}$ & $\begin{array}{l}\text { Bird } \\
\mathrm{s} \\
\text { and } \\
\text { fish }\end{array}$ \\
\hline Yaghub & Land & Water & Plants & Architecture & & & & & \\
\hline
\end{tabular}




\begin{tabular}{|c|c|c|c|c|c|c|c|c|}
\hline Daneshdust & & & & & & & & \\
\hline $\begin{array}{l}\text { Hossain } \\
\text { Soltanzade } \\
\text { h }\end{array}$ & $\begin{array}{l}\text { Constructi } \\
\text { onal } \\
\text { elements } \\
\text { and } \\
\text { phenomen } \\
\text { a }\end{array}$ & $\begin{array}{l}\text { Water } \\
\text { elements }\end{array}$ & $\begin{array}{l}\text { Herbal } \\
\text { element } \\
\text { s }\end{array}$ & $\begin{array}{l}\text { Communicatio } \\
\text { nal elements }\end{array}$ & & & & \\
\hline $\begin{array}{l}\text { Azadeh } \\
\text { Shahcherag } \\
\text { hi }\end{array}$ & $\begin{array}{l}\text { Culturing } \\
\text { system }\end{array}$ & $\begin{array}{l}\text { Water } \\
\text { system }\end{array}$ & $\begin{array}{l}\text { Buildin } \\
\text { gs } \\
\text { layout } \\
\text { system }\end{array}$ & $\begin{array}{l}\text { Landscape } \\
\text { system }\end{array}$ & $\begin{array}{l}\text { Shading } \\
\text { system }\end{array}$ & $\begin{array}{l}\text { Sounds } \\
\text { system }\end{array}$ & $\begin{array}{l}\text { Geometr } \\
\text { ic } \\
\text { structure } \\
\text { system }\end{array}$ & \\
\hline $\begin{array}{l}\text { M.R. } \\
\text { Poorjafar }\end{array}$ & $\begin{array}{l}\text { Layout } \\
\text { system }\end{array}$ & $\begin{array}{l}\text { access } \\
\text { and } \\
\text { approach } \\
\text { to space } \\
\text { system }\end{array}$ & $\begin{array}{l}\text { Space } \\
\text { geometr } \\
y\end{array}$ & $\begin{array}{ll}\text { Layout } & \text { of } \\
\text { buildings } & \text { in } \\
\text { space } & \end{array}$ & $\begin{array}{l}\text { The } \\
\text { moveme } \\
\text { nt } \\
\text { system } \\
\text { in space }\end{array}$ & $\begin{array}{l}\text { Enclosu } \\
\text { re } \\
\text { system } \\
\text { in space }\end{array}$ & $\begin{array}{l}\text { The } \\
\text { presence } \\
\text { and } \\
\text { moveme } \\
\text { nt of } \\
\text { water } \\
\text { system }\end{array}$ & $\begin{array}{l}\text { The } \\
\text { plants } \\
\text { cultivati } \\
\text { on } \\
\text { system }\end{array}$ \\
\hline
\end{tabular}

Reference: Author

\section{URBAN SPACE AND SOCIAL INTERACTION}

Urban spaces conveys specific functions such as the formation and shape of social interaction and creating preoccupation and sense of place. Improving the quality of human cultural life through the creation of an appropriate urban context for coexistence, cooperation and constructive engagement; are of urban planner's tasks. Communication and interaction with the community is the most basic principle of collective life. Human needs inherent social relations and therefore provides opportunities to experience social relationships. Social relationships are the different targets, or because of emotional reasons which are under the influence of kinship and friendly relations or rational (logical) reasons which seek to maximize the chances of people to reach this important goal. The ideal relationship is a reaction takes place between members of a community and helps them reach a common understanding of the meaning of life. Social interaction and culture are closely interwoven. Should bear in mind that social interactions are conducted in physical area and within a certain time. Some human activities happen in space and space is "a physical set for social interaction" (Tavalaee quotes Giddens, 2003, 111).

Proximity and confronting lead to conduct this important but it should be borne in mind that the place bed has great influence in shaping social interactions. A city can afford this who has the qualities required in order to achieve social stability. "Social desirability resulted in individuals interactions based on the social-friendly dimension of space namely the presence of people and various social groups and interactions between them"(Daneshpur and Charkhchian, 2007, 22). The sustainable city which absorbs the man as a national and encourage him to do the dialogue. Urban spaces can be a good context for social interactions, the urban area is of outdoor public spaces in which social interactions occur. "There is an opportunity in this space that some social boundaries become broken and non-preset interactions occur in a new social environment" (Lynch, 2002, 109). Urban spaces have different physical characteristics, openness; public involvement, good security and a great place for social interaction are among important characteristics of urban spaces. "Public open spaces are of particular importance in the collective life of citizens that usually provides most of actual and potential facilities for citizens presence and also are limited and controlled in terms of time" ( Pakzad, 2007, 57 ).

\section{SOCIAL INTERACTIONS}

One for different reasons and due to sedentary benefits by choosing this way of life, prefers social life compared to individual living. When the social human confronts the individual human, a mutual 
interaction occurs between members of a community in a location bed. When the interaction between the members of a society occurs the social relation has been conducted. Words of social control, social power and social capital are products of this choice each of which conveys different concepts and approaches. In order to do social interactions, are divided urban areas into three categories."

1. The public space: a space which is "accessible" for all members of society. 2. Semi-public or semiprivate space: A space that is open to the public, however, due to restrictions on its use and purpose, has specific users. 3. Private Space: a space that is occupied by people. "(Tavalaee quoting Rappaport, $2003,111)$. The public areas of the city are places for interaction between citizens. Various theories raise about social interaction and space. Somebody knows the space determining the social relationships and some look at space as the materialistic aspect of the society and knows social relations effective in shaping this. Some believe that space creates possibilities and conditions in which people select their cultural norms. In general, designers aim to create spaces as social space. "Social spaces are manifestation of social institutions that sociologists and geographers study them "(Madani Poor, 2013, 13). Humans have various functional response in urban spaces, in this context, their main activities in urban public spaces can be divided into three major groups, including "essential, voluntary and social activities which each requires specific physical conditions."(Talebi, 2004, 168). In these conditions, urban spaces can reflect cultural and social relations in the city. Some social communications are done in several ways, from ordinary greeting to participate in community events. "In general, all kinds of social interactions can be divided into two types of verbal communication and non-verbal (body language) communication" (Giddens, 2013, 120).

Both of these methods are important and partly affected by the physical form of urban space. In other words, how to achieve a cohesive and stable social relationship and promoting engagement and presence in public spaces requires that humans develop their knowledge about different patterns of socialization and this requires a wide range of studies in areas such as intra-race, intra-age, intra- sex and intra-cast interactions. This knowledge on one hand, needs content analysis, quantitative and qualitative studies consistent with the time and place of all relationships and on the other hand, requires the spatial analysis of components forming the platform of these relationships.

The relationship between landscape and health has long been considered in different cultures and societies. The presence of natural and artificial elements in the landscape with the help of five senses, made possible the environment perception for humans. This attitude that looking at water, grass, hearing the sounds of the natural elements (water movement and birds' song), breathing plants and flowers fragrance and taste and tactile stimuli, affect the five senses and focusing on them can be effective in reducing stress, in the past, the healing perspective included spiritual privacy and beautiful natural landscapes, while recently, this term has been abandoned and is only used for treatment in hospitals and clinics.

In fact, in different ways, the garden through creating a communication between humans, leads to healing and reduces the stress of everyday life. In fact, it can be said that "the success secret of the healing garden is due to humans' inherent trend to nature, feeling life and relaxation "(Nikbakht, 2004, 79). The perspective release one from stress and emotional pressure and will reinforce the people. Human's relation with environment through his five senses and the landscape provide an opportunity to experience, his senses are applied in nature as well but are organized in the healing landscape in a purposeful manner. Axes of healing landscape awakened a sense or senses in the audience and finally brings together, balance the five senses.

\section{PERSIAN GARDEN AND SOCIAL INTERACTION}

Persian gardens in his lifetime provides a lively and fun place for the users. The garden's elements and skeletal systems helped the Iranian architect in achieving such conditions. Meanwhile, the emergence of such a place encourages the man to stablish interactions and social communications. In the following, will be discussed about the circumstances of Persian Garden and the factors can be used in today's urban spaces in order to make social communications. 


\section{DIVERSITY OF THE LOCATION}

Persian Garden owning various places has been able to create different qualities in order to people as users, are provided a condition contributing dialogue and social interaction." Persian Garden is an enclosed area, with walls as the boundaries between inside and outside, shade and high humidity; where ultimately creates a refreshing atmosphere compared its neighbor hot environment "(Masoudi, 2003, 104). Plant, water and buildings are combined together in a distinctive architecture and are built an environment that is favorable, safe and comfortable for people. For example, "shadowy is planted around places of assembly or sitting in the garden, in some cities this place is called "Boneh Gah" where is summer living space"(Pirnia quoted From Shahcheraghi, 2010, 72).

The existence of such places lead Persian Garden to become the place for being. The combination of texture, form, color and function makes a diversity which its lack is accompanied to uniformity and increase the confusion. This is the same feature of the space component or varied perspective that creates a positive reaction in contrast to the environment. Such matters i.e. presence of sitting places for individuals in Persian Garden, can be considered a reason for social interaction. The user see himself in a happy, fun and relaxed space enclosed with human artifacts and natural elements of the garden and prepare the space for a dialogue.

\section{GREEN SPACE AND TREES}

In Persian Garden, plants have been cultured for different reasons. "Different purposes such as shading, productivity and garden decoration are applied" (Mahmoudi Nejad and others, 2006, 74). Furthermore, "the co-existence of different plants together and planting trees as a dry air filters for the garden are of Persian Garden features" ( Diba and Ansary, 1995, 41). Planting of greenery will minimize harsh artificial elements which are man-made, rises the sensory quality of the environment and provides a pleasant conceptual situation for the individual.

\section{WATER}

Water is used in Persian Garden in different ways such as fountains, falls, and river and so on. Sound and water appearance attract the audience's attention and separates him from the stressful environment, the sound of water is followed by the sense, formal and symbolic aesthetics and will have a direct impact on the human psyche. "One of the important characteristics of Persian Garden is the strong tend to show water and architect plays strange games with the water" (Pirnia, 2006, 6). Movement, the color of the water, the sound of water and even the existence of water in small and big pools are creating hope and life "(Daneshdust, 1990, 266).

\section{COLORFUL AND DECORATIVE FLOWERS}

Flowers and plants with a large variety of colors create variety of color combinations in different seasons. In addition, "this creates different combinations of fine or coarse textures which both have effects in the visual quality of the landscape and the diversity of tactile sensation" (Shahcheraghi, 2010, 71). Also, planting colorful flowers lead to special effects in mind as qualitative conceptual conditions. Accordingly, "paying attention to the color and its psychological effectiveness can affect the type and how users use the space and leads them to move and the dynamism or stagnation" (Mahmoudi Nejad and others, 2006, 133). Perception of shape, form, color and texture of flowers leads to regulation of human senses. Furthermore, is rooted the joy resulted from this in the values of the human sensory which itself has the capability to invite people to the environment and leads person to focus. On the other hand, floriculture in different seasons cause to change in terms of smelling which as a result, the environment will have different qualities for users.

\section{CONCLUSION}

Citizens need appropriate place to encourage dialogue and social interaction. Urban open spaces such as squares, parks, walking paths and green spaces are the manifestations of such places in order to meet such a need. Urban spaces need special physical conditions in order to invite people inside and encourage social interaction between citizens. Persian Garden and various elements which create it during the life of thousands of years, have been able to create an appropriate and desirable context for users and deploy him in a situation different from the world outside the garden. A happy, refreshing 
and lively world where is a human-made physical condition and helped the Iranian architect/ garden builder to create a desired location.

The emergence of Persian Garden is important and investigate that's why each of its various elements play a great role for the separation of humans from the around world. Given the ability of Persian Garden to provide a lively place where is needed for citizens in today's cities, can be used its various elements in urban open spaces. This spoliation should be done given the possibility of functionalbeing and effectiveness of each of the elements of the Persian garden in the current era and for the modern man according to his beliefs and needs. For example, the man is willing to open dialogue and interaction in places where invite persons inside. This is when the wall in Persian Garden ignores such a need. Table 3 provides the results of studies and research on the use of various elements of Persian Garden in urban spaces to carry out social interactions.

Table 3: various elements of Persian Garden in urban spaces, why to use and usage feasibility

\begin{tabular}{|c|c|c|}
\hline $\begin{array}{ll}\text { Persian } & \text { Garden's } \\
\text { elements } & \end{array}$ & Why to use & Usage feasibility \\
\hline Water & $\begin{array}{l}\text { Realistic, geometric role, } \\
\text { climatic }\end{array}$ & $\begin{array}{l}\text { There is a possibility to take advantage due } \\
\text { to mental conditions }\end{array}$ \\
\hline Wall & $\begin{array}{l}\text { Security , climatic, location } \\
\text { of the garden }\end{array}$ & $\begin{array}{l}\text { Impossible to use due to the need for social } \\
\text { interaction in spaces and open areas }\end{array}$ \\
\hline Geometry & $\begin{array}{l}\text { Geometric, operational and } \\
\text { doctrinal role }\end{array}$ & $\begin{array}{l}\text { There is a possibility to take advantage } \\
\text { provided to religious beliefs and } \\
\text { conditions of users }\end{array}$ \\
\hline Constructions & Need of individual users & $\begin{array}{l}\text { There are monuments to the public as } \\
\text { places of dialogue and interaction }\end{array}$ \\
\hline $\begin{array}{l}\text { Smell, sound and } \\
\text { shadow }\end{array}$ & $\begin{array}{l}\text { Creating a vibrant and lively } \\
\text { place and creating another } \\
\text { dimension of space }\end{array}$ & $\begin{array}{l}\text { A vibrant and lively context is needed for } \\
\text { dialogue and interaction }\end{array}$ \\
\hline
\end{tabular}

Reference: Author

\section{REFERENCES}

Chegini, N. (2002): Great Islamic Encyclopedia, Volume XI, Garden, Center for the Great Islamic Encyclopedia, the Press Ministry of Culture and Islamic Guidance, Tehran.

Daneshpur, S.A and Charkhchian, M (2007), Public spaces and factors affecting social life, Number Seven, Bagh-E-Nazar Magazine.

Danshdust, Y (1984), Persian Garden (lecture at the School of Architecture at the National University of Iran) Asar Quarterly, 18 and 19.

Danshdust, Y (1990), Tabas the city that was (Garden of Tabas), Cultural Heritage and Tourism Organization of Iran, Tehran.

Diba, Darab and Ansari, M. (1995), Persian Garden, Proceedings of the First Congress on Architectural History, Volume II, Tehran.

Irani Behbehani, H and Sultani, H. (2003): Indicators and features of gardens in Tehran in Qajar Era, Journal of Ecology, the studies on the environment, Special version on environment design, twentynine years, Tehran. 
Giddens, Anthony, Sociology (2013), translated by M. Sabouri, Ney Publications, Tehran.

Lynch, Kevin (2002), The theory of urban form, translation of Seyyed Hossein Bahraini, Tehran University Press.

Mate, Mohammad Karim (2006): Iranian Architecture, formulated by G.H. Memarian, Soroush Danesh Publications. Spring 2013, Tehran

Motedaien, H (21998), Persian Garden location, Proceedings of the conference on Persian Garden. Iranian Cultural Heritage and Tourism Organization.

Madani Poor civic, Ali, Translator; Mortezai, F. Urban design, an attitude toward a social and locational process. 2013. Published by the Information and Communication Technology Organization of Tehran Municipality, Tehran.

Mahmoudi Nejad, H and Ansari, M. (2006), Meta Architecture in Meta City, Construction and Computer Magazine, No. XV, the third year, December 2006.

Masoudi, A. (2003). The study on Persian Garden in a desert region (case study: Mahan Garden in Kerman, Iran), Doctoral Thesis in Science and Research Azad University - Faculty of Arts and Architecture.

Masoudi, A. (2003). Examining the wall as one of the separating components of Persian Garden, Architecture and Culture Quarterly, Vol. V, No. XIV, the summer 2003.

Mir Findereski, Mohammad Amin, 2004. What is Persian Garden? Where is Persian Garden? Proceedings of First conference of Persian Garden. Iranian Cultural Heritage and Tourism Organization of Iran, Tehran.

Mir Findereski, Mohammad Amin, 1995. The garden as the city's courtyard, Proceedings of the First Congress on Architectural and Urban Planning History, Volume V, Cultural Heritage and Tourism Organization of Iran, Tehran.

Nikbakht, A. (2004), Medicine in the modern landscaping, healing gardens. Bagh-E-Nazar Magazine, the second number.

Naeema, Gholam Reza (2006): Gardens of Iran: Iran is like a blooming spring garden, Payam Publications, Fall 2013, Tehran.

Pakzad, Jahānšāh (2007), Theoretical literature and urban design process, Shaheedi Publications.

Pourjafar, MR (2009), Analysis of the structural and formal systems dominant on Iran's landscape architecture, Utopia, No. 3, Fall and Winter 2009.

Pirnia, Mohammad Karim (2006): Understanding Islamic architecture, formulated by G.H. Memarian, Soroush Danesh Publications. Spring 2013, Tehran.

Soltanzadeh, H. (2003). From the garden to park, architecture doctoral dissertation titled "Reflections of tradition in contemporary architecture".

Shahcheraghi, A. (2010), Paradigms of the Heaven. The University of Jihad, Tehran.

Talebi, ZH, Social relations in the urban space, the Journal of Sociological Studies, 2004.

Tavalaee, N, Urban space and socio-cultural relations, Cultural Research Journal, 2003. 